\title{
Morphometric Analysis of Watershed of Sub-drainage of Godavari River in Marathwada, Ambad Region by using Remote Sensing
}

\author{
Ashok S. Sangle \\ Dept. Of CSIT, MGM Dr. G Y Pathrikar college of \\ CS \& IT, Maharashtra, India.
}

\author{
Pravin L. Yannawar \\ Vision and Intelligent System Lab, Dept. of CSIT, \\ Dr. BAMU Aurangabad, Maharashtra, India
}

\begin{abstract}
The use of GIS and remote sensing to prepare management and planning of natural resources of the geography is widely acknowledged. Progress in these technologies offers many advantages of taking a synoptic view of the natural resources, natural features at a glance to quicker planning and management of the end user related issues. This research work focuses on management of Natural resources used in water conservation, such as primarily drainage development, watershed evaluation and its characterization, harnessing the morphometric parameters of the topography. It's helpful in management of drought affected area and agriculture practices; finally enhances water tables and the requirement of water for food production ultimately full filled. The results were obtained with a DEM $90 \mathrm{~m}$ resolution and Toposheets data set reveals out that the watershed area was 204 sq.km. There were total 51 number of streams with cumulative stream length has $99.84 \mathrm{~km}$, drainage density has 0.48 , form factor has 0.19 , circulatory ratio has 0.2 , elongation ratio has 0.05 and bifurcation ratio has 2.73 of the characteristics of given basin topography.
\end{abstract}

\section{Keywords}

IRS- Indian remote Sensing, RS-Remote sensing, SOISurvey of India, LISS- Linear imaging self-scanning, SRTMShuttle radar Topography mission.

\section{INTRODUCTION}

Urbanization and heavy industrial growth has made its impact on the ecosystem and envrionment balance is potentially affected. Therefore, to increase the watershed conservation area and to reduce drought affected is a primary goal of government. To do so lots of efforts were taken into drainage development and characterizations of a watershed for storagelocation assessment and water harvesting. To accomplish this it is essential to understand the watershed characteristics like shape, stream pattern, and terrain features, etc. through the morphometric analysis, which helps in binding whole parameters for measurement of the shape of the watershed. It is basically better for agricultural practices. The natural resources management in a country where $70 \%$ population is based on agriculture related work has an immense important role to play not only in providing the economic goods but also maintaining and improving productivity of agriculture.
Natural resources management is the practical application of available knowledge of science and technology for the security, maximize production and benefits in agricultural practices through which conserving, preserving and improving the sustainable development were essentially achieved. In the interests of watershed management regulation of water flow, prevention of water runout, food security and maintain the ecological balance while meeting the requirement of the local population. Optimize the production under complex natural and socioeconomic circumstances by use of the integrated techniques.

The purposes, this research work is to describe the drainage, topography over drainage shape, shape, area, shape perimeter, drainage streams, stream length, and Stream hierarchynetwork etc. that is by use of the morphometric analysis or quantitative analysis. It is used to minimize the watershed related issues and depictions of the watershed topography. So it helps to better plan ultimate for land use/land cover, agricultural practices.

The content of this research paper is organized in 4 sections, the recent Section 1 introduction, Section 2 deals with Study area, Section 3 describes the Methodology, Section 4 presents the discussion over Result obtained and visualization part followed by conclusions and references.

\section{STUDY AREA}

The study area for this research work is a part of the Godavari river sub drainage. It is located at Gahininath Nagar, is a small Village of Ambad Taluka located in Jalna District of Maharashtra State (India). It comes under Gahininath Nagar $\mathrm{Nv}$ Panchayath. It is located $32 \mathrm{KM}$ towards the south from Jalna district headquarters and $369 \mathrm{KM}$ from state capital Mumbai. The watershed area geographically located between $19^{\circ} 21^{\prime}-19^{\circ} 34^{\prime}$ North Latitude and $75^{\circ} 35^{\prime}-75^{\circ} 47^{\prime}$ East Longitude, Figure 1 shows the location of the study area on district map. 


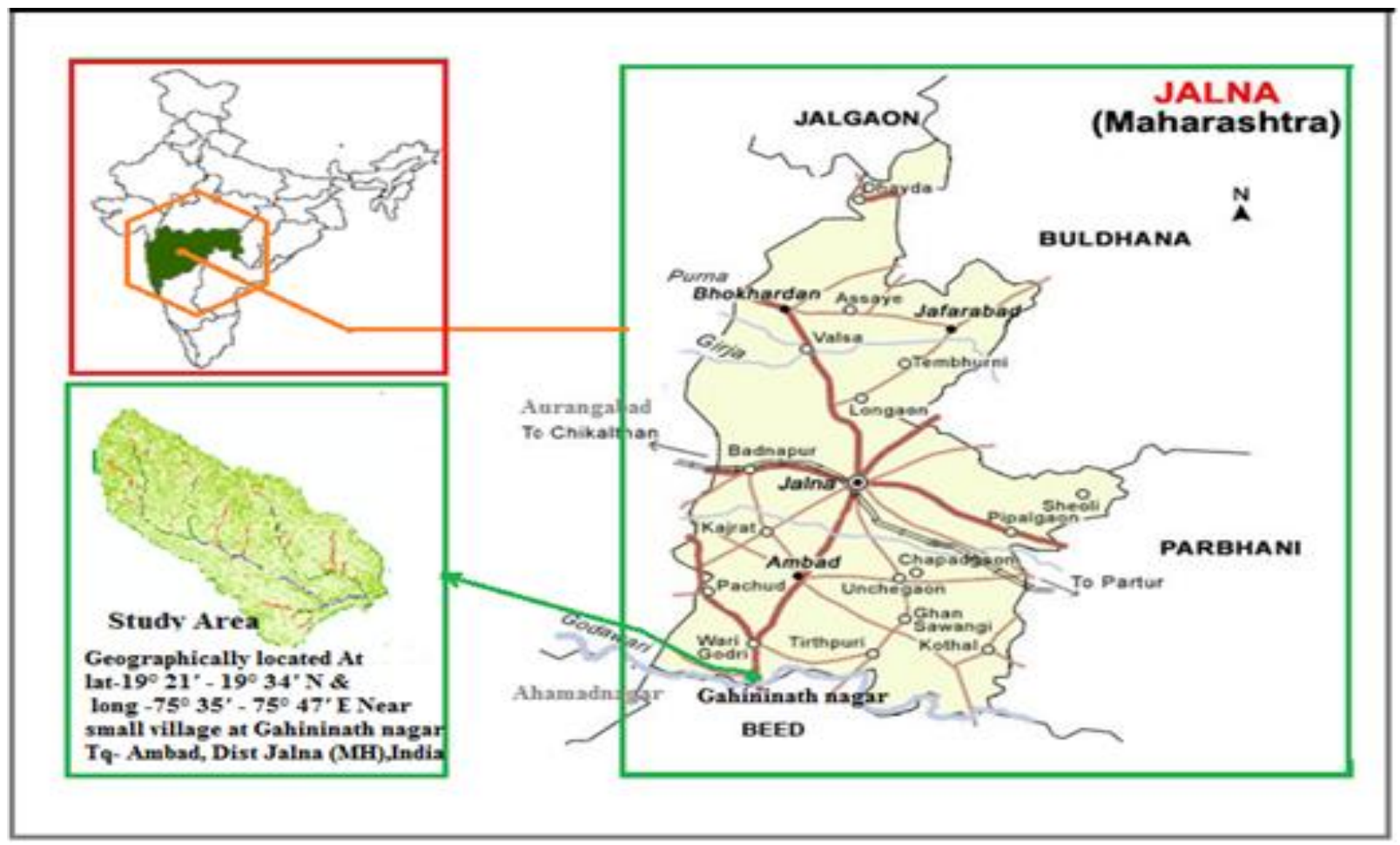

Figure 1: Location of the given Study area

\section{METHODOLOGY}

Morphometric analysis is considered the best method for isolation of problem through which precise descriptions of the geometry of landforms could be harnessed as data could be collected, organized, analysed and visualized using remote sensing integrated with GIS techniques to resolve the given application complexity. As concern this aspect here required the appropriate raw data to input for integration. The following primarily data and tool were collected and used for this study $[1,2,3,4]$.

- Input row data: SRTM 90 m resolution DEM data and for local knowledge SOI toposheets of scale $1: 250000,1: 50000$

- $\quad$ Software tool: ArcGIS 9.3 tools with extension Arc Hydro tool.

In this watershed analysis, research work the ArcGIS 9.3 software tools with Arc Hydro extensions was utilized, because it is fully functional geographic data processing supportive environment, software tool. It handles Remote Sensing raster data as well as secondary sources, GIS data like toposheets, maps, etc. through the sort of process-orders such as Data Acquisition. In data processing aspect where features were constructed on, Identify region of interest (rough ROI), The determination of Drainage Watershed Boundary (i.e. Exact enough ROI), Derive Drainage Network and Stream Order then Apply Some Morphometric Analysis refers following figure 2 .

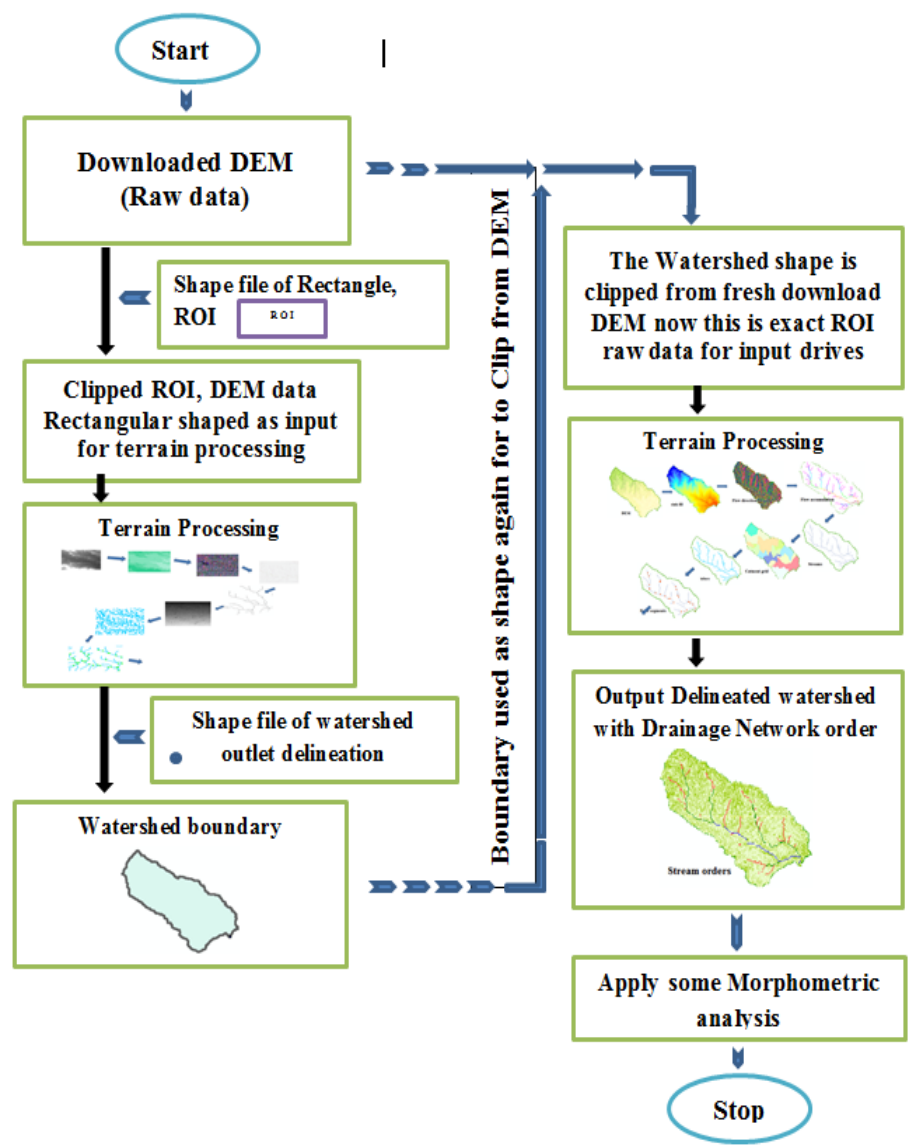

Figure 2: Shows a systematic way of data processing steps

In data processing by use of the auto-algorithm where applied the threshold value on to given DEM and get an appropriate 
watershed boundary. This watershed boundary clipped from prearranged fresh DEM to find out the appropriate watershed shape sized drainage network and stream order. It is due to one can easily apply some morphometric analysis for watershed evaluation, characterization, for the purpose of water conservation and drainage development $[1,2,3,4]$.

\section{DISCUSSION OF RESULT}

The size of the drainage and basins vary greatly with the order of the streams. The Ordering of the streams is the first stage of watershed analysis. As per the Strahler's method this proposed drainage watershed is ordered. It is the watershed as the 3 rd order drainage basin. As shown in table 1 and in figure 3.

\subsection{Drainage Area (Au)}

The entire area drained by streams or by streams pattern in such way that all streams flow originating in the area is discharged through a single outlet is termed as the Drainage Area. The given study, an area considered for work was measured to be 204 square $\mathrm{km}$.

\subsection{Basin length ( $\mathrm{Lb})$}

Basin length is the longest dimension of a basin to its principal drainage channel. It covers the length is $32.03 \mathrm{~km}$.

\subsection{Bifurcation Ratio}

The Bifurcation Ratio has of fundamental importance in drainage basin analysis. It helps to have an idea about the shape of the basin as well as in making out the run off behaviour. The bifurcation ratio will not be exactly the same from one order to the next order because of the possibility of the changes in the watershed geometry and lithology but will tend to be consistent throughout the series. In the experiment on the data set the mean bifurcation ratio was observed to be $2.730[5,6]$.

\subsection{Basin Relief $(\mathrm{Bh})$}

Basin relief is the elevation difference of the highest and lowest point of the valley/basin it was $0.091 \mathrm{Km}[7,8]$.

\subsection{Form Factor (Rf), Circularity Ratio (Rc), Elongation Ratio (Re)}

The Form Factor (Rf), Circularity Ratio (Rc) and Elongation Ratio $(\mathrm{Re})$ are commonly used to represent the different basin shapes. The $\mathrm{Rf}=0.19, \mathrm{Rc}=0.28$ and $\mathrm{Re}=0.05$ it strongly agreed the shape of the study area that is elongated in shape refer figure 2 . The shape of the basin mainly governs the rate at which the water is supplied to the main channel. Three parameters viz. Elongation Ratio (Re), Circulatory Ratio (Rc) and Form Factor (Rf) are used for characterizing the drainage basin shape, which is an important parameter from the hydrological point of view $[5,7,10,11-13]$.

\subsection{Drainage Density (Dd)}

It reflects the land use and affects infiltration and the basin response time between precipitation and discharge. Drainage basin with high Dd indicates that a large proportion of the precipitation runs off. On the other hand, a low drainage density indicates the most rainfall infiltrates the ground and few channels are required to carry the runoff. So, given watershed area is $\mathrm{Dd}=0.489$ then its nature observed out as a flat terrain [17].

\subsection{Drainage Frequency (Fs)}

Drainage frequency may be directly related to the lithological characteristics. The number of stream segments per unit area is termed Stream Frequency or drainage Frequency it was 0.25 sq. $\mathrm{Km}[7,16]$.

Table 1: Drainage Basin Morphometry Worksheet

\begin{tabular}{|c|c|c|}
\hline Sr.No. & Variable & Watershed \\
\hline 01 & Area $\left(\mathrm{km}^{2}\right)$ & 204 \\
\hline 02 & Perimeter Length (km) & 94.137 \\
\hline 03 & Gradient (longest path) & 32.031 \\
\hline 04 & Drainage Pattern (Name) & Dendritic \\
\hline 05 & Number of 1st Order Streams (no.) & 26 \\
\hline 06 & Number of 2nd Order Streams (no.) & 18 \\
\hline 07 & Number of 3rd Order Streams (no.) & 7 \\
\hline 08 & Order of Master Stream (Strahler) & 3 \\
\hline 09 & Length of 1st Order Streams (km) & 47.966 \\
\hline 10 & Length of 2nd Order Streams (km) & 34.765 \\
\hline 11 & Length of 3rd Order Streams (km) & 17.109 \\
\hline 12 & Sum of all Stream Lengths $(\mathrm{km})$ & 99.841 \\
\hline 13 & $\begin{array}{l}\text { 2nd Order Bifurcation Ratio } \\
\text { (No1st/No2nd) }\end{array}$ & 1.44 \\
\hline 14 & $\begin{array}{l}\text { 3rd Order Bifurcation Ratio } \\
\text { (No2nd/No3rd) }\end{array}$ & 2.57 \\
\hline 15 & Mean of Bifurcation ratio & 2.730 \\
\hline
\end{tabular}


Table 2: Formulae for computation of Morphometry parameters

\begin{tabular}{|c|c|c|c|c|}
\hline $\begin{array}{l}\text { Sr. } \\
\text { no. }\end{array}$ & Morphometric Parameters & Symbol/Formula & Observed values & Reference \\
\hline 1 & Watershed Area $(\mathrm{Km})^{2}$ & A & 204 & -- \\
\hline 2 & Perimeter $(\mathrm{Km})$ & $\mathrm{P}$ & 94.137 & -- \\
\hline 3 & Basin Length (Lb) Km & $\mathrm{Lb}$ & 32.031 & -- \\
\hline 4 & Stream Order $(\mathrm{u})$ & u (Hierarchical Order) & 3 & [15] \\
\hline 5 & Mean Stream Length (Lsm) & $\mathrm{Lsm}=\mathrm{Lu} / \mathrm{Nu}$ & 1.957 & {$[15]$} \\
\hline 6 & Ruggedness number (RN) & $\mathrm{Rn}=(\mathrm{Bh})^{*}(\mathrm{Dd})$ & 0.185 & {$[15]$} \\
\hline 7 & $\begin{array}{l}\text { Total number of stream segments in } \\
\text { all orders }\end{array}$ & $(\mathrm{Nu})$ & 51 & [16] \\
\hline 8 & Stream Length of all Orders & $(\mathrm{Lu})$ & 99.841 & [16] \\
\hline 9 & Texture Ratio (Rt) Km & $\mathrm{Rt}=\mathrm{Nu} / \mathrm{P}$ & 0.541 & [16] \\
\hline 10 & Form factor (Rf) & $\mathrm{R}_{\mathrm{f}}=\mathrm{A} /(\mathrm{Lb})^{2}$ & 0.198 & [16] \\
\hline 11 & Drainage Density (Dd ) km/km2 & $\mathrm{Dd}=\mathrm{Lu} / \mathrm{A}$ & 0.489 & {$[17]$} \\
\hline 12 & Stream Frequency $(\mathrm{Fs})(\mathrm{Km}) 2$ & $\mathrm{Fs}=\mathrm{Nu} / \mathrm{A}$ & 0.25 & {$[17]$} \\
\hline 13 & Mean Bifurcation Ratio (Rbm) & $\begin{array}{c}\mathrm{Rbm}=\text { avarage of bifurcation ratio } \\
(\mathrm{Rb}=\mathrm{Nu} / \mathrm{Nu}+1) \text { all orders }\end{array}$ & 2.73 & [18] \\
\hline 14 & Basin Relief (Bh) km & $\mathrm{Bh}=\mathrm{Hmax}-\mathrm{Hmin}$ & 0.091 & [19] \\
\hline 15 & Relief Ratio (Rh) km & $\mathrm{Rh}=\mathrm{Bh} / \mathrm{Lb}$ & 0.0028 & [19] \\
\hline 16 & Elongation Ratio $(\mathrm{Re})$ & $R e=(1 / L b)(4 A \pi)^{0.5-}$ & 0.05 & [19] \\
\hline 17 & Circulatory Ratio (Rc) & $\mathrm{Rc}=4 \pi \mathrm{A} / \mathrm{P}^{2}$ & 0.289 & [20] \\
\hline 18 & $\begin{array}{l}\text { Constant channel maintenance (C) } \\
\mathrm{km}\end{array}$ & $\mathrm{C}=1 / \mathrm{Dd}$ & 2.043 & [21] \\
\hline
\end{tabular}

\subsection{Visualization}

In this phase visualized the final output in pictorial form. It should fit the purpose clearly indicating the idea about characterization with its shape and stream order at a glance.

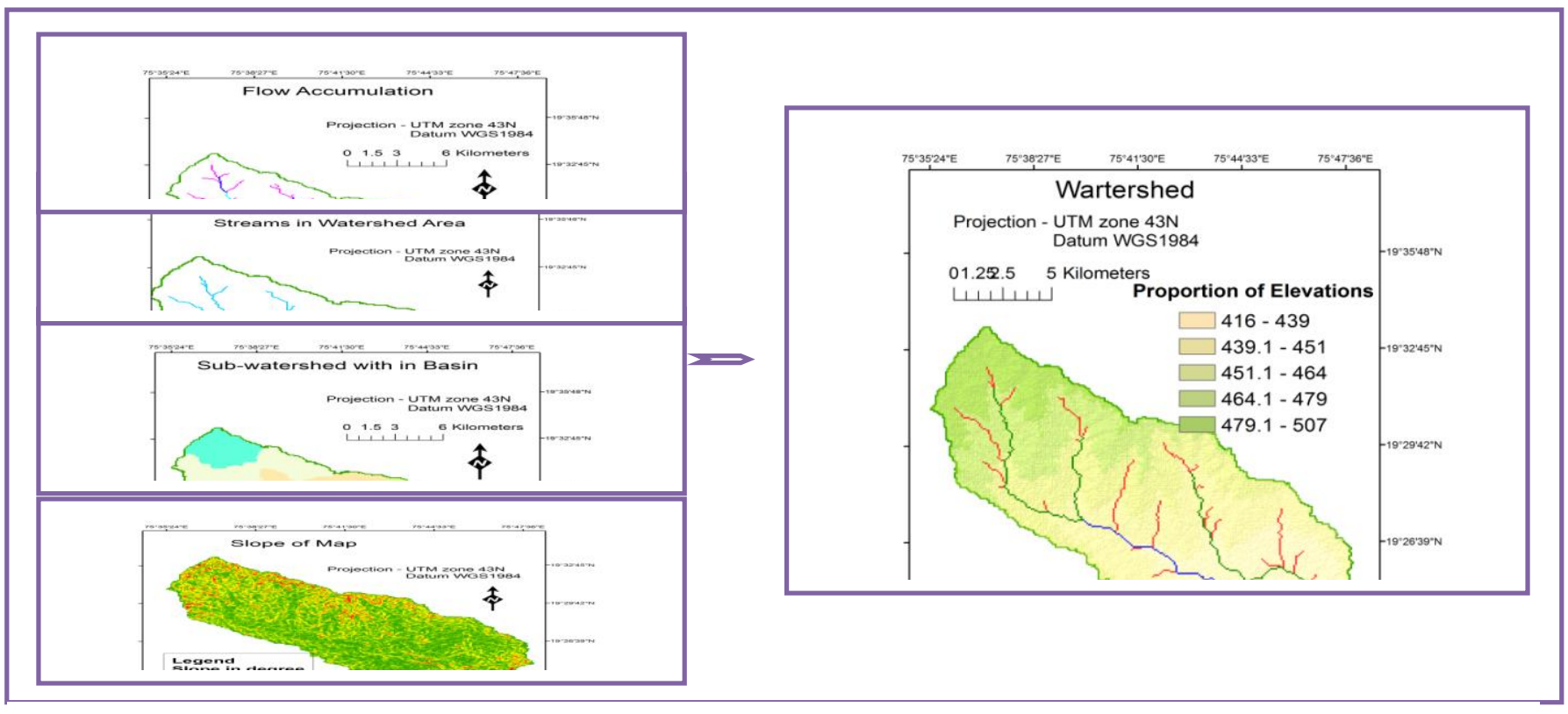




\section{CONCLUSION}

The drainage morphometric analysis of the study area reveals that the watershed can be characterized by elongation ratio, circulatory ratio and form factor. The result shows that the characterization of drainage on the basis of the parameters values. The few parameter values are considered here those are as a elongation ratio was 0.05 which defines that the watershed is strongly elongated, circularity ratio was observed to be 0.2 it is also a evidence as strongly elongated watershed and again from factor also observed 0.19 , this also indicate that it is elongated in shape and bifurcation ratio observed 2.73 it indicate that the region is in flat in the landscape (shape). It inferences the flat region and elongated drainage basins with low from factor has a lower subsequent flow of larger durations. Generally the watershed topography formed due to rainfall, Slope and aspect so the watersheds have an infinite variety of shapes and the shape supposedly reflects the way that runoff will bunch up at the outlet. So the evaluated and analysed morphometric parameters such as area, length, stream pattern, flow direction, and perimeters all these are reflect the shape and topography of the given watershed. The scope of research work focuses on the management of Natural resources used in water conservation, such as primarily watershed evaluation, its characterization and drainage development etc. to avoid drought affected area for better agricultural practices.

\section{REFERENCES}

[1] Joe wheaton, "Watershed Delineation - Advanced GIS Courses: WATS USU." [Online]. Available: http://gis.joewheaton.org/assignments/labs/lab-8--choice/lab08a/task-1---watershed-delineation. [Accessed: 25-Nov-2014].

[2] D. Tarboton, M. David, and O. Robayo, "Watershed Delineation from Digital Elevation Models," 07-Aug$2004 . \quad$ [Online]. Available: http://www.crwr.utexas.edu/gis/gishydro04/Introduction/ Exercises/Ex4.htm. [Accessed: 26-Nov-2014].

[3] Lt. Col. P.N. Koul: GIS- Its Concepts and Application in forestry, Digital Cartography and DEM. Reference Notes of Forest Survey of India, Dec-2006.

[4] K.P. Sharma: GIS: Concepts and Methods, Application of Geographic information System and RS in working plan preparation. Reference Notes of Forest Survey of India, Nov-2007.

[5] Pupil vision, "Basin Networks," 27-Jun-2010. [Online]. Available:

http://www.pupilvision.com/uppersixth/rivers1.htm. [Accessed: 11-Oct-2013].

[6] Essays, "Overview Of Drainage Basin Morphometry Environmental Sciences Essay," Nov-2013. [Online]. Available:

http://www.ukessays.com/essays/environmentalsciences/overview-of-drainage-basin-morphometryenvironmental-sciences-essay.php. [Accessed: 2-Apr2014].

[7] R. Palaka and G. Jai Sankar, "Study of Watershed Characteristics using Google Elevation Service," India Geospatial Digest March 2014,. [Online]. Available: http://www.researchgate.net/publication/260595644_Stu dy_of_Watershed_Characteristics_using_Google_Elevati on_Service.
[8] Khadri, S.F.R, and K. Moharir, "Detailed morphometric analysis of Man River Basin in Akola and Buldhana Districts of Maharashtra, India is using Cartosat-1 (DEM) Data and GIS techniques," International Journal of Scientific \& Engineering Research, vol. 4, no. 11, Nov. 2013.

[9] M. A. Bermudez-Cella, P. van der Beek, and Matthias Bernet, "Tectonic versus climatic control on exhumation and relief development in the Venezuelan Andes," Geological Society of America, p. 01-, 2009.

[10] M. A. Hassan and A. A. . Selman, "Morphometric Properties of Bulkana (Naft Khanah) North-East Iraq from Topographic Maps," International Journal of Current Engineering and Technology, vol. 4, no. 1, pp. 45-51, 2014. [Online]. Available: http://www.researchgate.net/publication/259969140_Mor phometric_Properties_of_Bulkana_\%28Naft_Khanah\%2 9_North-East_Iraq_from_Topographic_Maps.

[Accessed: 25-Apr-2015]

[11] F. Altaf, G. Meraj, and S. A. Romshoo, "Morphometric Analysis to Infer Hydrological Behaviour of Lidder Watershed, Western Himalaya, India," Geography Journal, vol. 2013, p. e178021, Apr. 2013.

[12] S. A. Ali and N. Khan, "Evaluation of Morphometric Parameters-A Remote Sensing and GIS Based Approach," Open Journal of Modern Hydrology, vol. 03, no. 01 , pp. 20-27, 2013.

[13] Rasool. Q. A., Vivek Kumar Singh, and Singh U. C., "Read Microsoft Word - EIJES2136," International Journal Of Environmental Sciences, vol. 1, no. 7, Aug. 2011.

[14] J. I. Clark, "Morphometry from Maps Essay in geomorphology", Elsevier publishing company, New York, 1966, pp.235-274.

[15] A.N. Strahler, (1964), Quantitative Geomorphology of Drainage basins and channel networks. "Handbook of Applied Hydrology", In V. T. Chow (Ed.) New York: McGraw Hill., pp 4, 39-4 and 76.

[16] Horton, R.E., (1945), Erosional development of steam and their drainage basin. Hydrogeological approach to quantitative morphology, Bulletin of Geological Society of America, 56, pp 275-370.

[17] R. E. Horton, "Drainage Basin Characteristics," Transactions of American Geophysical Union, Vol. 13, 1932, pp. 350-361. doi:10.1029/TR013i001p00350.

[18] A. Strahler, "Quantitative analysis of watershed geomorphology," Transactions American Geophysical Union, vol. 38, pp913-920, 1957.

[19] S. A. Schumn, "Evolution of Drainage Systems and Slopes in Badlands at Perth Amboy, New Jersey," Bulletin of the Geological Society of America, Vol. 67, No. 5, 1956, pp. 597-646. doi:10.1130/00167606(1956)67[597:EODSAS]2.0.CO;2.

[20] V. C. Miller, (1953) "A Quantitavie Geomorphic Study of Drain- age Basin Characteristics in the Clinch Mountain Area, Virgina and Tennessee," Department of Geology, Co- lumbia University, New York, 1953.

[21] M. Suresh, S. Shudhakar, K. N. Tiwari and V. M. Chowdary, "Prioritization of watersheds using 
morphometric parameters and assessment of surface water potential using remote sing," Journal of the Indian Society of Remote Sensing, Vol. 32, no. 3, 2004.

[22] S. Rais and A. Javed, "Identification of Artificial Recharge Sites in Manchi Basin, Eastern Rajasthan (India) Using Remote Sensing and GIS Techniques," Journal of Geographic Information System, vol. 06, no. 02, pp. 162-175, 2014.

[23] Eze Bassey Eze \& Joel Efiong, "Morphometric Parameters of the Calabar River Basin: Implication for Hydrologic Processes", Journal of Geography and Geology, vol.2, no. 1, September 2010.

[24] Panhalkar S. S., Mali S. P., Pawar C. T. "Morphometric Analysis and Watershed Development Prioritization of
Hiranyakeshi Basin in Maharashtra, India " International Journal of Environmental Science, volume 3 no. 12012.

[25] Sujata Biswas, S. Sudhakar and V. R. Desai, "Prioritization of Subwatersheds Based on Morphometric Analysis of Drainage Basin: A Remote Sensing and GIS Approach", Photonirvachak Journal of the Indian Society of Remote Sensing, vol. 27, no. 3, 1999.

[26] G. Tamma Rao, V.V.S. Gurunadha Rao, Ratnakar dakate, S.T. Mallikharjuna Rao and B. M. Raja Rao, "Remote Sensing and GIS Based Comparative Morphometric Study of Two Sub-watershed of Different Physiographic Conditions, West Godavari District, A. P.”, Journal Geological Society of India vol.79, april 2012, pp.383-390. 